\title{
Sympathetic Nerve Control of Blood Pressure Response during Exercise in Peripheral Artery Disease and Current Application of Experimental Disease Models
}

\author{
Lu Qin and Jianhua Li* \\ Heart \& Vascular Institute, The Penn State University College of Medicine, US
}

*Corresponding author: Jianhua Li, Heart \& Vascular Institute, The Penn State University College of Medicine, Hershey, PA 17033, USA. To Cite This Article: Jianhua Li. Sympathetic Nerve Control of Blood Pressure Response during Exercise in Peripheral Artery Disease and Current Application of Experimental Disease Models. 2020 - 9(3). AJBSR.MS.ID.001387. DOI: 10.34297/AJBSR.2020.09.001387.

Received: 啙 March 14, 2020; Published: 㘹 June 26, 2020

\begin{abstract}
In patients with peripheral artery disease (PAD), the blood supply directed to the lower limbs is reduced. This results in severe limb ischemia and thereby intermittent claudicating which is characterized by pain in lower limbs that occurs with walking and is relieved by rest. Of note, PAD can extremely affect the quality of living of patients and increase high risk of coronary and cerebral vascular accidents. However, effective treatments of PAD are still challenging in clinics. A number of reports have demonstrated the beneficial effects of supervised exercise on symptoms of PAD patients. This review will summarize results obtained from recent human and animal studies, which include the abnormalities in sympathetic control of blood pressure response during exercise in PAD, and rationality of animal models used for study human PAD. Nonetheless, additional in-depth studies are necessary to better explore the underlying mechanisms of the exaggerated responses of sympathetic nerve and blood pressure in PAD at molecular and cellular levels.
\end{abstract}

Keywords: Peripheral Artery Disease; Sympathetic Nerve Activity; Blood Pressure; Exercise; Muscle Contraction

\section{Introduction}

Peripheral artery disease (PAD) is a common and disabling disease affecting 12 to $20 \%$ of Americans over age 60 [1,2]. It is caused by atherosclerotic vascular disease that results in progressive narrowing of the lower extremity conduit vasculature. PAD can lead to severe limb ischemia. Thus, the classic discomfort syndrome of PAD is termed "intermittent claudication" which is characterized by pain in lower limbs that occurs with walking and is relieved by rest. This in turn limits walking tolerance. Importantly, PAD patients are at high risk of myocardial infarctions, cerebral vascular high risk of myocardial infarctions, cerebral vascular accidents and all-cause mortality [3] with a death rate similar to that seen in patients with coronary or cerebral vascular disease.
There are several treatment options for PAD [4,5]. Angioplasty or surgery is necessary to treat PAD causing claudicating. These procedures can improve the affected artery and increase blood flow to the affected tissues. Symptom-relief drugs such as cilostazol increase blood flow to the limbs by widening the blood vessels and increasing the thin blood, which helps improve symptoms of claudication and leg pain in PAD patients. In addition, medicines are prescribed to prevent blood clots, lower BP and cholesterol, and alleviate pain. In particular, medications to prevent blood clots are used to patients because PAD is related to a decrease in blood flow to the limbs and it's important to improve the flow. If there is a blood clot blocking an artery, thrombolytic therapy is also selected by injecting a clot-dissolving drug into the artery. In addition 
to surgery and/or medications, a supervised exercise training program increases the distance patients can walk painlessly.

In spite of the treatment and intervention strategies, relative to the major advances seen in the management of other cardiovascular diseases (e.g. coronary artery disease and systolic heart failure) therapeutic options other than surgery for PAD remain currently limited $[4,5]$. Among them, numerous drugs have been evaluated for use in patients with claudication symptoms, but efficacy has only been reported for cilostazol and anti-platelet agents [6]. In fact, exercise training (advice to walk more often) is commonly recommended for PAD patients and supervised treadmill exercise is supported by studies $[7,8]$. However, the implementation of exercise into the daily lives of PAD patients is met with significant challenges (e.g. pain in the legs upon exertion). Moreover, the blood pressure (BP) response to exercise is exaggerated in PAD patients [9-12]. It is important to note that augmented BP responses during exercise are associated with higher incidence of cardiovascular disease [13]. Thus, identifying the molecular mediators that can decrease the exaggerated BP responses to exercise in PAD patients has clear clinical relevance.

\section{Sympathetic nerve and BP responses during exercise in PAD}

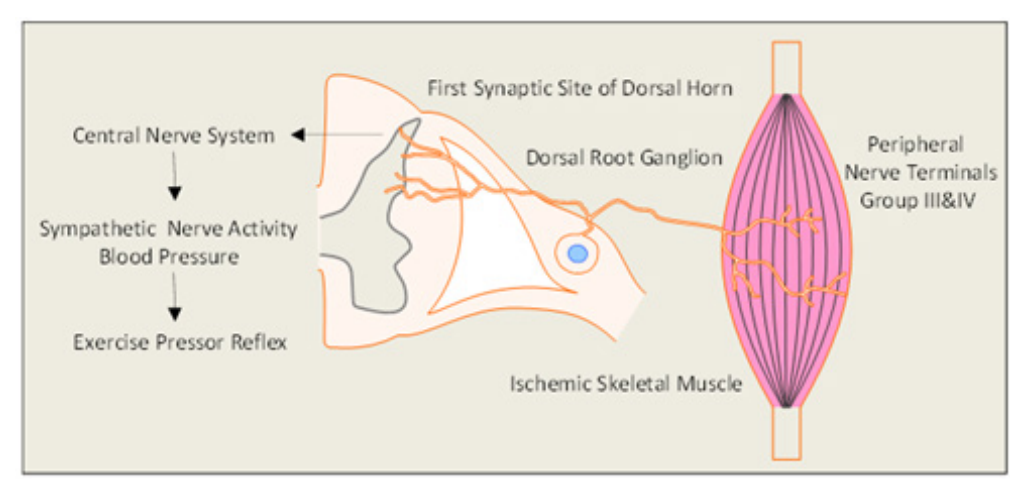

Figure 1: The diagram describes the neural pathway for the exercise pressor reflex and the role of the hind limb muscle ischemia. In peripheral artery disease,the responses of sympathetic nervous activity and blood pressure are amplified during exercise. Using a rat model of peripheral artery disease, a number of studies demonstrated that the protein expression of several receptors in dorsal root ganglion are unregulated and current amplitude of sensory neurons with stimulation of these receptors are increased, thereby leading to the exaggerated exercise pressor reflex.

The sympathetic nervous system is activated during exercise. This contributes to the increases in BP, heart rate (HR), myocardial contractility and peripheral vasoconstriction $[14,15]$. There are two basic mechanisms are thought to contribute to sympathetic engagement during exercise. The first termed "Central Command" [16], suggests that motor and sympathetic activation occur in parallel, i.e. there is a volitional signal emanating from central motor areas that leads to increased sympathetic activation during exercise. This system is linked to skeletal muscle metabolic needs via parallel brain activation of motor and autonomic centers [16]. The second termed the "Exercise Press or Reflex" [17,18] Figure 1 suggests that afferents arising from contracting skeletal muscle initiate an autonomic reflex. The metabolic stimulation (metabo receptor activation) and mechanical deformation of the muscle afferents receptive field (mechanoreceptor activation) [17]. Group IV and III afferents are thought to be predominantly metabolic sensitive and mechanically sensitive, respectively [17]. When these receptors are activated in thin fiber muscle afferent nerves, cardiovascular nuclei in the brainstem are stimulated thereby leading to increases in sympathetic nervous activity (SNA) and BP [18].
The BP rises during walking in the PAD patients are significantly greater than that seen in healthy control subjects $[9,10]$. Moreover, the BP response during the exercise with the "diseased" limb is greater than that during the exercise with the "non-diseased" limb [11]. Recent human studies from our institute further indicate that BP and renal vasoconstriction responses during plantar flexion exercise are accentuated in PAD [12-19]. Thus, it is believed that an exaggerated exercise presser reflex is a major determinant of why BP rises with exercise in PAD [20] (Figure 1). In addition, PAD is associated with reduced functional capacity and increased risk for cardiovascular morbidity and mortality, as well as the reduced quality of life [21]. Moreover, it has been found that the leg revascularization attenuates the augmented BP and HR in response to exercise in PAD patients, along with the greater coronary blood velocity [22]. Nonetheless, to our knowledge, studies on the SNA and BP responses to the stimulation of chemically and mechanically sensitive afferents in PAD are still lacking. Researchers have taken advantage of animal models to study human PAD and further to explore the underlying mechanisms of the exaggerated exercise pressor reflex in PAD at molecular and cellular levels. 


\section{Animal Models Used for Study Of Pad}

Previous studies have shown that the SNA and BP responses to static exercise and activation of muscle metabolite receptors (i.e., TRPV1, TRPA1, P2X and ASIC3) are augmented in PAD rats [23,24]. Other muscle afferents' receptors such as $\mu$-opioid and thromboxane (TP) receptor are also involved in the reflex BP response to static muscle contraction in PAD [23,24]. DAMGO $\mu$-opioid receptor stimulator significantly inhibits BP response to static contraction in PAD rats [24]. Daltroban, a TP receptor antagonist, administered into the hind limb muscles attenuates the cardiovascular responses to muscle contraction and tendon stretch in PAD rats [24]. Recent findings further indicate that blocking bradykinin B2 and PGE2 EP4, and stimulation of peripheral $\delta$-opioid receptors can alleviate the mechanical component of the exaggerated exercise pressor reflex in PAD rats [25-27].

The primary purpose of the animal PAD model is to eliminate the blood flow in the affect limbs and therefore mimics the etiology and pathology characteristics of the PAD patients. In the last decades, the efforts have been made to enhance the ischemia degree and to extend the time length for the ischemia phase by restricting the blood supply from the collateral circulation. In this review, we summarized the features of representative animal models of PAD in addition to a rat model of PAD induced by femoral artery ligation (Table 1). There are currently several models of PAD used to study human PAD and pathophysiology of limb ischemia. In general, a surgical ligation of the femoral artery and excision is commonly used to restrict limb blood flow and to study ischemia and ischemia-induced pain in small animals such as mice and rats [28-33]. To extend injury in tissues, in the previous studies branches of the femoral artery were also ligated to exaggerate limb ischemia $[31,33]$. Surgical ligation of the external iliac artery and double ligation models clearly demonstrated to limit blood flow to the limbs to a greater degree [34-37]. Endovascular occlusion is also one of the most effective models to limit blood flow and it is also inducing less surgical procedure-induced injury to the external wall of the artery and the surrounding tissues. Due to its procedure technique, it is currently limited to be observed in animals such as rabbit and swine [38,39]. Interestingly, apart from inducing occlusion by performing surgical procedures, elements of $\mathrm{FeCl} 2$ have been reported to induce thrombus in the artery and therefore theFeCl2 induced-ischemic model in rats was also developed. This model is closely related to thrombus-induced ischemia and pain under clotting conditions in PAD patients [40]. Nevertheless, various animal models are worthwhile to study the exercise pressor reflex in PAD which has numerous pathophysiological causes. It is should be noted that a simple model of artery ligation may not reflect PAD due to complicated atherosclerotic vascular disorders, but may represent of pathophysiology of limb ischemia which excludes confound effects seen commonly in experimental disease models.

Table 1.

\begin{tabular}{|c|c|c|c|c|c|}
\hline Species & Genders & Age/weight & Model & Surgery procedures and ischemia measurements & References \\
\hline Wistar rats & M & $200-240 \mathrm{~g}$ & $\begin{array}{l}\text { Femoral artery ligation } \\
\text { and excision }\end{array}$ & $\begin{array}{l}\text { Two silk ligatures were tied around the artery } \sim 1 \mathrm{~cm} \\
\text { proximal to the epigastric bifurcation and the artery was } \\
\text { cut between the ligatures }\end{array}$ & $\begin{array}{l}\text { Hayes et al. } \\
\quad[30]\end{array}$ \\
\hline C57BL/6 mice & $\mathrm{F}$ & 6 months; $25-35 \mathrm{~g}$ & $\begin{array}{l}\text { Femoral and saphenous } \\
\text { artery ligation, and } \\
\text { exercised the femoral } \\
\text { artery and all attached } \\
\text { branches }\end{array}$ & $\begin{array}{l}\text { The blood flow started to recover at day } 7 \text { post-surgery } \\
\text { and achieved the plateau from day } 28 \text { to } 35 \text { post-surgery }\end{array}$ & $\begin{array}{l}\text { Couffinhal et } \\
\text { al. [29] }\end{array}$ \\
\hline \multirow{4}{*}{$\begin{array}{l}\text { New Zealand } \\
\text { White Rabbit }\end{array}$} & \multirow{4}{*}{$\mathrm{F}$} & \multirow{4}{*}{ N/A } & \multirow{4}{*}{$\begin{array}{l}\text { Endovascular occlusion } \\
\text { and surgical occlusion } \\
\text { model }\end{array}$} & $\begin{array}{l}\text {-Endovascular occlusion model: Six fibered platinum } \\
\text { endovascular coils were used to occlude the superficial } \\
\text { femoral artery (SFA) }\end{array}$ & \multirow{4}{*}{$\begin{array}{l}\text { Liddell et al } \\
\quad[38]\end{array}$} \\
\hline & & & & $\begin{array}{l}\text {-Surgical Occlusion model: The SFA was then ligated just } \\
\text { distal to the lateral circumflex branch and just proxi- } \\
\text { mal to its bifurcation into the saphenous and popliteal } \\
\text { arteries }\end{array}$ & \\
\hline & & & & -The ligated segment of the SFA was completely excised. & \\
\hline & & & & $\begin{array}{l}\text {-The endovascular occlusion model induced less of an } \\
\text { arteriogenic response compared with the surgical model }\end{array}$ & \\
\hline \multirow[t]{2}{*}{ C57BL/6 mice } & \multirow[t]{2}{*}{ M } & \multirow[t]{2}{*}{$8-12$ weeks } & \multirow[t]{2}{*}{$\begin{array}{l}\text { Femoral/saphenous } \\
\text { artery excision model }\end{array}$} & $\begin{array}{l}\text {-The proximal of the femoral artery and the distal } \\
\text { portion of saphenous artery were ligated. All branches } \\
\text { between these two sites were ligated or cauterized, and } \\
\text { arteriectomy was performed. }\end{array}$ & \multirow[t]{2}{*}{ Yu et al. [33] } \\
\hline & & & & $\begin{array}{c}\text { - The blood flow recovered to baseline in } 4 \text { weeks } \\
\text { post-surgery }\end{array}$ & \\
\hline
\end{tabular}




\begin{tabular}{|c|c|c|c|c|c|}
\hline \multirow{2}{*}{$\begin{array}{l}\text { Sprague-Daw- } \\
\quad \text { ley rats }\end{array}$} & \multirow{2}{*}{ M } & \multirow{2}{*}{$300-350 \mathrm{~g}$} & \multirow{2}{*}{$\begin{array}{c}\mathrm{FeCl}_{2} \text { induced ischemia } \\
\text { model }\end{array}$} & $\begin{array}{l}\text {-The femoral artery was separated from the femoral vein } \\
\text { and nerve by a piece of moisture-resistant film. A filter } \\
\text { paper disc soaked with } 20 \% \mathrm{FeCl}_{2} \text { solution was placed on } \\
\text { the femoral artery for } 20 \mathrm{~min}\end{array}$ & \multirow{2}{*}{$\begin{array}{l}\text { Seo et al. } \\
\quad[40]\end{array}$} \\
\hline & & & & $\begin{array}{c}\text {-Compared with the contralateral leg, the Evan's blue } \\
\text { concentration were lower in ipsilateral leg at day } 3 \text { and } 9 \\
\text { post-surgery and recover to the same as contralateral leg } \\
\text { at day } 31 \text { post-surgery }\end{array}$ & \\
\hline $\begin{array}{l}\text { Sprague-Daw- } \\
\quad \text { ley rats }\end{array}$ & M & $250-300 \mathrm{~g}$ & Femoral artery excision & $\begin{array}{c}\text {-Compared with sham, the model induced a decrease in } \\
\text { blood flow by } 80 \% \text { at } 10 \text { minutes post-surgery, and the } \\
\text { blood flow recovers to } \sim 30 \% \text { as sham group at day } 21 \\
\text { post-surgery }\end{array}$ & $\begin{array}{l}\text { Bitto et al. } \\
\quad[28]\end{array}$ \\
\hline Mice & N/A & N/A & Femoral artery ligation & $\begin{array}{l}\text {-Ligation of the femoral artery distal to the origin of the } \\
\text { deep branch by a triple surgical knot and if necessary, } \\
\text { conduct the proximal femoral ligation and excision of the } \\
\text { femoral bifurcation with all branches }\end{array}$ & $\begin{array}{l}\text { Limbourg et } \\
\text { al. [31] }\end{array}$ \\
\hline \multirow{3}{*}{ C57Bl/6 mice } & \multirow{3}{*}{ M } & \multirow{3}{*}{$\begin{array}{l}3 \text { months and } 18 \\
\text { months }\end{array}$} & \multirow{3}{*}{$\begin{array}{l}\text { Unilateral common iliac } \\
\text { artery and vein ligation }\end{array}$} & $\begin{array}{l}\text {-Compared with femoral artery ligation, iliac model does } \\
\text { not require an incision in the ischemic limb }\end{array}$ & \multirow{3}{*}{$\begin{array}{l}\text { Westvik et al. } \\
\quad[35]\end{array}$} \\
\hline & & & & $\begin{array}{l}\text {-In young adult mice, blood flow dropped rapidly after } \\
\text { arterial ligation and returned slowly over } 4 \text { weeks, } \\
\text { achieving } 60 \% \text { of pre-procedural flow by } 2 \text { weeks }\end{array}$ & \\
\hline & & & & $\begin{array}{l}\text {-In aged mice, with the operative procedures blood flow } \\
\text { was reduced by a similar amount, but in contrast, flow } \\
\text { remained approximately } 25 \% \text { of baseline and did not } \\
\text { recover }\end{array}$ & \\
\hline \multirow[t]{2}{*}{ Yorkshire swine } & \multirow[t]{2}{*}{$\mathrm{F}$} & \multirow[t]{2}{*}{ 6-8 months } & \multirow[t]{2}{*}{ Endovascular model } & $\begin{array}{l}\text {-With the assistance of fluoroscopy, the wire was ad- } \\
\text { vanced into the superficial femoral artery from the right } \\
\text { common carotid artery, a stent and vascular plug were } \\
\text { implanted through the location from external iliac artery } \\
\text { and common femoral artery }\end{array}$ & \multirow[t]{2}{*}{$\begin{array}{l}\text { Long et al. } \\
\text { [39] }\end{array}$} \\
\hline & & & & $\begin{array}{l}\text {-Velocities in the ligated limb decreased and recovered to } \\
38 \% \text { of the baseline in } 5 \text { weeks after the occlusion }\end{array}$ & \\
\hline \multirow[b]{2}{*}{$\begin{array}{l}\mathrm{BALB} / \mathrm{c} \\
\text { C57BL } / 6 \text { and } \\
\text { FVB mice }\end{array}$} & \multirow[b]{2}{*}{ M } & \multirow[b]{2}{*}{$8-10$ weeks } & \multirow[b]{2}{*}{$\begin{array}{l}\text { Femoral artery and vein } \\
\text { ligation }\end{array}$} & $\begin{array}{c}\text {-Femoral artery and vein were ligated proximally below } \\
\text { the inguinal ligament }\end{array}$ & \multirow[b]{2}{*}{$\begin{array}{l}\text { Parikh et al. } \\
\text { [39] }\end{array}$} \\
\hline & & & & $\begin{array}{l}\text {-This model was designed as the model for hind limb } \\
\text { gangrene, the ischemia index (ligated/unligated limb } \\
\text { reperfusion) was lower than } 0.2 \text { at } 21 \text { days post-surgery } \\
\text { in BALB/c mice }\end{array}$ & \\
\hline \multirow[t]{2}{*}{ C57BL/6 mice } & \multirow[t]{2}{*}{ M } & \multirow[t]{2}{*}{$\begin{array}{l}\text { 10-12 weeks; } \\
\text { 20-30g }\end{array}$} & \multirow[t]{2}{*}{$\begin{array}{l}\text { Double femoral artery } \\
\text { ligation }\end{array}$} & $\begin{array}{c}\text {-Ligation of the femoral artery directly distal to the su- } \\
\text { perficial epigastric artery; a second ligation was placed } \\
\text { around the lateral circumflex artery to diminish femoral } \\
\text { artery run-off }\end{array}$ & \multirow[t]{2}{*}{$\begin{array}{l}\text { Schuler et al. } \\
\text { [34] }\end{array}$} \\
\hline & & & & $\begin{array}{l}\text {-The perfusion unit dropped to } \sim 10 \% \text { in post-ligation, } \\
\text { and recovered by } \sim 40 \% \text { in day } 14 \text { post-operation }\end{array}$ & \\
\hline \multirow[b]{2}{*}{ Mice } & \multirow[b]{2}{*}{ N/A } & \multirow[b]{2}{*}{$\mathrm{N} / \mathrm{A}$} & $\begin{array}{l}\text { Femoral artery transec- } \\
\text { tion model; }\end{array}$ & $\begin{array}{l}\text {-The femoral artery transection model: two ligatures } \\
\text { around the femoral artery (not the vein), before transec- } \\
\text { tion of the intervening segment }\end{array}$ & \multirow[b]{2}{*}{ Yu et al. [36] } \\
\hline & & & $\begin{array}{l}\text { Femoral/saphenous } \\
\text { artery excision model }\end{array}$ & $\begin{array}{l}\text {-The femoral/saphenous artery excision model: upper } \\
\text { ligature around the femoral artery, middle ligature } \\
\text { around the popliteal/saphenous artery bifurcation, and } \\
\text { the lower ligature around the saphenous artery }\end{array}$ & \\
\hline $\mathrm{BALB} / \mathrm{c}$ mice & M & N/A & $\begin{array}{l}\text { External iliac ligation } \\
\text { and excision }\end{array}$ & $\begin{array}{l}\text { - The external iliac artery was ligated above the puden- } \\
\text { doepigastric trunk proximal to the deep femoral artery } \\
\text { twice and dissected between the two ligations }\end{array}$ & $\begin{array}{l}\text { Goggi et al. } \\
\text { [37] }\end{array}$ \\
\hline
\end{tabular}




\section{Future Perspective}

Atherosclerotic vascular disease is a main cause of PAD and intermittent claudication is the most common symptom of this disease which can be altered during exercise. A suitable exercise activity has benefits for patients with PAD [41]. However, pain and fatigue associated with the disease restrict exercise. Moreover, amplified BP response and reduced muscle blood flow controlled by SNA during exercise in PAD patients increases the risks for other cardiovascular diseases. Using a rat model of PAD, we have explored the role of metabolite sensitive receptors on muscle afferent nerves in regulating the sympathetic and pressor responses in PAD. Whereas this PAD rat model is primarily based on limiting limb blood flow; it has limitations to reflect complex of this disease in pathophysiology because of atherosclerotic vascular disorders of PAD. Therefore, experimental strategies need to be addressed in the future by 1) performing the similar studies using different animal model of PAD or a combination of multiple models, 2) performing the similar experiments in conscious animals corresponding to humans, and 3) examining the effect of certain interventions alleviating the exaggerated exercise pressor reflex function and further improving the claudication and/or exercise incapacity in PAD. Nevertheless, in the future animal models of more representative human PAD are desired to be developed.

\section{Acknowledgements}

This study was supported by NIH P01 HL134609 and R01 HL141198.

\section{Reference}

1. Criqui MH, Aboyans V (2015) Epidemiology of peripheral artery disease. Circ Res 116(9): 1509-1526.

2. Fowkes FG, Aboyans V, Fowkes FJ, McDermott MM, Sampson UK, et al. (2017) Peripheral artery disease: epidemiology and global perspectives. Nat Rev Cardiol 14(3): 156-170.

3. Ouriel K (2001) Peripheral arterial disease. Lancet 358(9289): 12571264.

4. Hirsch AT, Haskal ZJ, Hertzer NR, Bakal CW, Creager MA, et al. (2006) ACC/AHA Guidelines for the Management of Patients with Peripheral Arterial Disease (lower extremity, renal, mesenteric, and abdominal aortic): a collaborative report from the American Associations for Vascular Surgery/Society for Vascular Surgery, Society for Cardiovascular Angiography and Interventions, Society for Vascular Medicine and Biology, Society of Interventional Radiology, and the ACC/ AHA Task Force on Practice Guidelines (writing committee to develop guidelines for the management of patients with peripheral arterial disease)--summary of recommendations. J Vasc Interv Radiol 17: 13831397; quiz 1398.

5. Olin JW, White CJ, Armstrong EJ, Kadian-Dodov D, Hiatt WR (2016) Peripheral Artery Disease: Evolving Role of Exercise, Medical Therapy, and Endovascular Options. J Am Coll Cardiol 67(11): 1338-1357.

6. Clagett GP, Sobel M, Jackson MR, Lip GYH, Tangelder M, (2004) Antithrombotic Therapy in Peripheral Arterial Occlusive Disease. The Seventh ACCP Conference on Antithrombotic and Thrombolytic Therapy. Chest 126(3): 609S-626S.
7. Brendle DC, Joseph LJ, Corretti MC, Gardner AW, Katzel LI (2001) Effects of exercise rehabilitation on endothelial reactivity in older patients with peripheral arterial disease. Am J Cardiol 87(3): 324-329.

8. Hamburg NM, Balady GJ (2011) Exercise rehabilitation in peripheral artery disease: functional impact and mechanisms of benefits. Circulation 123(1): 87-97.

9. Baccelli G, Reggiani P, Mattioli A, Corbellini E, Garducci S (1999) The exercise pressor reflex and changes in radial arterial pressure and heart rate during walking in patients with arteriosclerosis obliterans. Angiology 50(5): 361-374.

10. Bakke EF, Hisdal J, Jorgensen JJ, Kroese A, Stranden E (2007) Blood pressure in patients with intermittent claudication increases continuously during walking. Eur J Vasc Endovasc Surg 33(1): 20-25.

11. Lorentsen E (1972) Systemic arterial blood pressure during exercise in patients with atherosclerosis obliterans of the lower limbs. Circulation 46(2): 257-263.

12. Muller MD, Drew RC, Blaha CA, Mast JL, Cui J, et al. (2012) Oxidative stress contributes to the augmented exercise pressor reflex in peripheral arterial disease patients. J Physiol 590(23): 6237-6246.

13. Lewis G D, Gona P, Larson M G, Plehn J F, Benjamin E J, O’Donnell C J, et al. (2008) Exercise blood pressure and the risk of incident cardiovascular disease (from the Framingham Heart Study). Am J Cardiol 101(11): 1614-1620.

14. Sinoway L, Prophet S, Gorman I, Mosher T, Shenberger J, et al. (1989) Muscle Acidosis during Static Exercise Is Associated with Calf Vasoconstriction. J Appl Physiol 66(1): 429-436.

15. Victor R G, Bertocci L, Pryor S, Nunnally R (1988) Sympathetic nerve discharge is coupled to muscle cell $\mathrm{pH}$ during exercise in humans. J Clin Invest 82(4): 1301-1305.

16. Waldrop TG, Eldridge FL, Iwamoto GA, Mitchell JH (1996) Central neural control of respiration and circulation during exercise. Chapter 9. In: L B Rowell, J T Shepherd (Eds.), Handbook of Physiology - Section 12, Exercise: Regulation and Integration of Multiple Systems, Oxford University Press, New York, USA, pp. 333-380.

17. Kaufman M P, Forster H V (1996) Reflexes controlling circulatory, ventilatory and airway responses to exercise. Chapter 10. In: L B Rowell, J T Shepherd (Eds.), Handbook of Physiology - Section 12, Exercise: Regulation and Integration of Multiple Systems, Oxford University Press, New York, USA, pp. 381-447.

18. Mitchell JH, Kaufman MP, Iwamoto GA (1983) The exercise pressor reflex: Its cardiovascular effects, afferent mechanism, and central pathways. Ann Rev Physiol 45: 229-242.

19. Drew R C, Muller M D, Blaha C A, Mast J L, Heffernan M J, et al. (2013) Renal vasoconstriction is augmented during exercise in patients with peripheral arterial disease. Physiol Rep 1(6): 1-9.

20. Ritti-Dias RM, Meneses AL, Parker DE, Montgomery PS, Khurana A, (2011) Cardiovascular responses to walking in patients with peripheral artery disease. Med Sci Sports Exerc 43(11): 2017-2023.

21. Hiatt WR, Fowkes FG, Heizer G, Berger JS, Baumgartner I, et al. (2017) Ticagrelor versus Clopidogrel in Symptomatic Peripheral Artery Disease. N Engl J Med 376: 32-40.

22. Miller AJ, Luck JC, Kim DJ, Leuenberger UA, Aziz F, et al. (2018) Peripheral revascularization attenuates the exercise pressor reflex and increases coronary exercise hyperemia in peripheral arterial disease. J Appl Physiol 125(1): 58-63.

23. Li J, Xing J (2012) Muscle afferent receptors engaged in augmented sympathetic responsiveness in peripheral artery disease. Front Physiol 3: 247. 
24. Stone AJ, Kaufman MP (2015) The exercise pressor reflex and periphera artery disease. Auton Neurosci 188: 69-73.

25. Leal AK, Stone AJ, Yamauchi K, McCord JL, Kaufman MP (2013) Blockade of $\mathrm{B} 2$ receptors attenuates the responses of group III afferents to static contraction. Neurosci Lett 555: 231-236.

26. Lu J, Xing J, Li J (2013) Bradykinin B2 receptor contributes to the exaggerated muscle mechanoreflex in rats with femoral artery occlusion. Am J Physiol Heart Circ Physiol 304(8): H1166-1174.

27. Yamauchi K, Kim JS, Stone AJ, Ruiz-Velasco V, Kaufman MP (2013) Endoperoxide 4 receptors play a role in evoking the exercise pressor reflex in rats with simulated peripheral artery disease. J Physiol 591(11) 2949-2962.

28. Bitto A, Polito F, Altavilla D, Minutoli L, Migliorato A, et al. (2008) Polydeoxyribonucleotide (PDRN) restores blood flow in an experimental model of peripheral artery occlusive disease. J Vasc Surg 48(5): 12921300 .

29. Couffinhal T, Silver M, Zheng LP, Kearney M, Witzenbichler B, et al (1998) Mouse model of angiogenesis. Am J Pathol 152(6): 1667-1679.

30. Hayes DJ, Challiss RA, Radda GK (1986) An investigation of arteria insufficiency in rat hindlimb. An enzymic, mitochondrial and histological study. Biochem J 236(2): 469-473.

31. Limbourg A, Korff T, Napp LC, Schaper W, Drexler H, et al. (2009) Evaluation of postnatal arteriogenesis and angiogenesis in a mouse model of hind-limb ischemia. Nat Protoc 4(12): 1737-1746.

32. Parikh PP, Castilla D, Lassance-Soares RM, Shao H, Regueiro M, et al. (2018) A Reliable Mouse Model of Hind limb Gangrene. Ann Vasc Surg 48: 222-232.

33. Yu J, deMuinck ED, Zhuang Z, Drinane M, Kauser K, et al. (2005) Endothelial nitric oxide synthase is critical for ischemic remodeling mural cell recruitment, and blood flow reserve. Proc Natl Acad Sci U S A 102(31): 10999-11004.
34. Schuler D, Sansone R, Nicolaus C, Kelm M, Heiss C (2018) Repetitive remote occlusion (RRO) stimulates eNOS-dependent blood flow and collateral expansion in hindlimb ischemia. Free Radic Biol Med 129: 520-531.

35. Westvik TS, Fitzgerald TN, Muto A, Maloney SP, Pimiento JM, et al. (2009) Limb ischemia after iliac ligation in aged mice stimulates angiogenesis without arteriogenesis. J Vasc Surg 49(2): 464-473.

36. Yu J, Dardik A (2018) A Murine Model of Hind Limb Ischemia to Study Angiogenesis and Arteriogenesis. Methods Mol Biol 1717: 135-143.

37. Goggi JL, Haslop A, Boominathan R, Chan K, Soh V, et al. (2019) Imaging the Proangiogenic Effects of Cardiovascular Drugs in a Diabetic Model of Limb Ischemia. Contrast Media Mol Imaging 2019: 2538909.

38. Liddell RP, Patel TH, Weiss CR, Lee DS, Matsuhashi T, et al. (2005) Endovascular model of rabbit hindlimb ischemia: a platform to evaluate therapeutic angiogenesis. J Vasc Interv Radiol 16(7): 991-998.

39. Long CA, Timmins LH, Koutakis P, Goodchild TT, Lefer DJ, et al. (2017) An endovascular model of ischemic myopathy from peripheral arterial disease. J Vasc Surg 66(3): 891-901.

40. Seo HS, Kim HW, Roh DH, Yoon SY, Kwon YB, et al. (2008) A new rat model for thrombus-induced ischemic pain (TIIP); development of bilateral mechanical allodynia. Pain 139(3): 520-532.

41. McDermott MM, Liu K, Ferrucci L, Criqui MH, Greenland P, et al. (2006) Physical performance in peripheral arterial disease: a slower rate of decline in patients who walk more. Ann Intern Med 144(1): 10-20 